\title{
PENINGKATAN KESIAGAAN BENCANA GEMPA BUMI MELALUI PENDEKATAN DRILLING
}

\author{
Harianto Manalu ${ }^{1}$, Yunus Elon ${ }^{2}$ \\ ${ }^{1,2}$ Fakultas Ilmu Keperawatan Universitas Advent Indonesia \\ e-mail: harianto.twjo@gmail.com \\ (Diterima 20-06-2019; disetujui 25-06-2019; dipublish 23-8-2019)
}

\begin{abstract}
ABSTRAK
Latar belakang: Kabupaten Bandung Barat, merupakan salah satu kabupaten di Jawa Barat yang menjadi primadona wisata. Dibalik pesona alam yang indah terdapat resiko yang tinggi terhadap bencana alam. Untuk mengurangi tingkat resiko yang terjadi akibat bencana, dibutuhkan ketangguhan setiap mahasiswa melalui pemahaman tentang tindakan saat gempa. Tujuan: Penelitian ini bertujuan untuk mendeskripsikan tingkat kesiagaan mahasiswa saat sebelum dan sesudah promosi dan drilling siaga gempa. Metode: Populasi dalam penelitian ini adalah mahasiswa/I UNAI yang mengikuti semester padat sebanyak 270 orang. Sampel dipilih dengan menggunakan metode non-probability sampling yang berjumlah 39 orang dari berbagai Fakultas dan Program studi. Kesiapan diobservasi pada sebelum dan sesudah drilling dengan menggunakan lembar check list yang diadopsi dari Buku Pedoman Kesiap-siagaan terhadap Bencana yang diterbitkan oleh BNPB tahun 2017. Hasil: tingkat kesiagaan mahasiswa terhadap bencana gempa saat sebelum dilakukannya promosi dan drilling yaitu $(40,5 \%)$ atau masuk kategori rendah, dan saat setelah promosi dan drilling kesiagaan bencana gempa didapati tinggi $(92,48 \%)$ dan berbeda secara signifikan dengan p value $>.05$. Kesimpulan: Hasil penelitian ini menunjukkan bahwa promosi dan drilling kesiagaan bencana gempa mampu meningkatkan tingkat kesiagaan mahasiswa terhadap gempa bumi.
\end{abstract}

Kata kunci: Promosi kesiagaan gempa, Drilling, Tingkat kesiagaan gempa.

\section{ABSTRACT}

Background: West Bandung Regency, is one of the regencies in West Java that is a tourist favourite. Behind the beautiful charm of nature, there is a high risk of natural disasters. To reduce the level of risk that occurs due to disasters, it takes the resilience of each student through an understanding of the actions during the earthquake. Objective: This study aims to describe the level of student preparedness before and after promotion and drilling earthquake alerts. Method: The population in this study were UNAI students / I who participated in a solid semester of 270 people. The sample was chosen using a non-probability sampling method which amounted to 39 people from various faculties and study programs. Readiness was observed before and after drilling using a checklist sheet adopted from the Disaster Preparedness Guidebook published by BNPB in 2017. Result: The level of student readiness for earthquake disasters before the promotion and drilling is done (40.5\%) or entering the low category, and when after the promotion and drilling of earthquake disaster preparedness found high (92.48\%) and significantly different from $p$ value $>.05$. Conclusion: The results of this study indicate that the promotion and drilling of earthquake disaster preparedness can increase the level of student alertness to earthquakes.

Keywords: Earthquake preparedness promotion, Drilling, Earthquake alertness level.

\section{PENDAHULUAN}

Bencana merupakan kejadian yang tidak diinginkan oleh siapapun, namun demikian kondisi tersebut dapat terjadi kapan saja, dimana saja dan kepada siapa saja. Salah satu bencana yang sering terjadi yaitu, gempa bumi. Gempa bumi merupakan kondisi yang terjadi akibat getaran dipermukaan bumi yang mengahasilkan gelombang seismik. Gempa dengan kekuatan 9,0, magnitude yang tejadi di Jepang pada tahun 2011 merupakan gempa terbesar yang mengakibatkan terjadinya gelombang tsunami (Mercalli, 2015). Dari tahun 2010-2019 jumlah kematian akibat gempa 
bumi, sebanyak 794.629 orang, atau ratarata 52.975 .27 orang meninggal akibat gempa setiap tahunnya, dan selain kematian, gempa juga mengakibatkan kerugian yang sangat besar (Statista, 2016).

Indonesia merupakan negara yang sangat subur namun wilayahnya rawan terhadap bencana alam, salah satunya adalah bencana gempa bumi. Secara geografis, Indonesia terletak pada pertemuan empat lempeng tektonik di dunia, yaitu lempeng benua Asia dan benua Australia, serta lempeng samudera Hindia dan samudera Pasifik, hal inilah yang membuat Indonesia rawan akan bencana gempa bumi maupun tsunami (Riki, 2018).

Menurut data statistic BNPB (2019) dalam 10 tahun terakhir, jumlah kejadian akibat gempa bumi yaitu 191 dimana korban yang meninggal sebanyak 2.097, luka-luka 10.841, menderita dan mengungsi, 984,780 serta ratusan ribu rumah, serta fasilitas umum dan pendidikan mengalami kerusakan. dan untuk propinsi Jawa Barat jumlah gempa bumi dalam 10 tahun terakhir sebanyak 23 kali, dimana 127 orang meninggal, 1,320 luka-luka, mengungsi 204.734 serta kerusakan properti puluhan ribu. Banyaknya korban jiwa yang muncul, diakibatkan oleh kurangnya pengetahuan masyarakat tentang mitigasi bencana. Sehingga masyarakat perlu pemahaman bagaimana menghadapi bencana gempa bumi. Tempat pendidikan merupakan wahana yang efektif dalam menyebarkan informasi, pengetahuan dan keterampilan, (Amri, 2017)

Salah satu program yang dijalankan oleh pemerintah untuk meningkatkan kesiapsiagaan yaitu promosi. Menurut Wawan dan Dewi (2010), promosi merupakan suautu kegiatan atau usaha menyampaikan pesan kepada masyarakat, kelompok atau individu. Dengan harapan bahwa dengan adanya pesan tersebut masyarakat, kelompok, atau individu dapat memperoleh pengetahuan yang lebih baik.

Secara umum sangat sedikit anggota masyarakat yang mengetahui apa yang harus dilakukan pada saat terjadi gempa. Berdasarkan pengamatan pada saat terjadinya gempa di wilayah Bandung pada hari Kamis 11 Oktober 2018 terlihat bahwa mahasiswa Universitas Advent Indonesia yang berada di dalam kelas mengalami kepanikan. Sebagai respons terhadap gempa dengan magnitudo 6,5 tersebut dengan melompat dari lantai 2 gedung. Dengan data ini peneliti melihat perlunya intervensi keperawatan kepada masysrakat dengan pendekatan promosi dan drilling kesiapsiagaan gempa bumi.

\section{METODE}

Populasi dalam penelitian ini adalah mahasiswa peserta semester padat 2018/2019 sebanyak 270 orang yang berada di kampus Universitas Advent Indonesia (UNAI). Metode yang digunakan dalam penelitian ini adalah quasi eksperimental design,dengan rancangan One Group Pre-Test and Post- 
Test. Responden dipilih dengan teknik non-probability sampling dari berbagai

Fakultas dan program studi..

Prosedur pengambilan data dan dokumentasi dilakukan setelah mendapatkan ijin pelaksaaan penelitian. Calon responden yang merupakan mahasiswa UNAI diundang untuk mengikuti promosi dan drilling kesiapsiagaan bencana. Calon responden yang hadir diberi penjelasan tentang maksud dan tujuan dari penelitian. Responden yang bersedia berpartisipasi diminta untuk menandatangani informed consent, dan sclanjutnya mengikuti program promosi dan drilling yang merupakan intervensi yang berlangsung selama dua kali 60 menit. Sebelum dan sesudah intervensi tersebut setiap peserta dikondisikan pada simulasi gempa. Respon masing-masing peserta direkam dengan 4 kamera kemudian dianalisa dengan instrument check list yang diadopsi dari Buku Pedoman Kesiapsiagaan terhadap Bencana yang diterbitkan oleh BNPB tahun 2017.

\section{HASIL DAN PEMBAHASAN}

Responden yang terlibat dalam penelitian ini adalah sebanyak 39 mahasiswa UNAI dengan karakteristik yang ditunjukkan dalam tabel 1 .

Tabel 1

Karakteristik Responden

\begin{tabular}{cccc}
\hline Karakteristik & & F & Percent \\
\hline Jenis Kelamin & Wanita & 26 & $66.7 \%$ \\
& Pria & 13 & $33.3 \%$ \\
& Total & 39 & 100.0 \\
\hline F=Frequency & & &
\end{tabular}

Berdasarkan tabel 1 dapat diketahui gambaran karakteristik responden berdasarkan jenis kelamin dimana responden yang paling banyak adalah wanita sebanyak 26 responden $(66,7 \%)$.

Pria 13 responden $(33,3 \%)$.

Tabel 2

Sumebr dan informasi gempa yang diperoleh responden.

\begin{tabular}{lll}
\hline Informasi gempa & Frequency & Percent \\
\hline TV & 2 & $5.1 \%$ \\
Beberapa sumber & 37 & $94.9 \%$ \\
Total & 39 & 100.0 \\
\hline
\end{tabular}

Tabel 2 menenjukkan bahwa sumber informasi tentang gempa yang diperoleh responden yang paling banyak adalah dari beberapa sumber 37 responden dengan $(94,9 \%)$, dan yang paling sedikit informasi dari TV 2 responden dengan $(5,1 \%)$.

Tabel 3

Gambaran tingkat kesiap siagaan bencana sebelum dan sesudah drilling.

\begin{tabular}{|c|c|c|c|c|c|c|c|c|c|c|}
\hline \multirow{3}{*}{ No } & \multirow{3}{*}{$\begin{array}{c}\text { Pernyataan } \\
\text { Tindakan Kesiagaan saat } \\
\text { Bencana }\end{array}$} & \multicolumn{4}{|c|}{ Nilai Pre-test } & \multicolumn{4}{|c|}{ Nilai Post-test } & \multirow{3}{*}{$\begin{array}{l}\text { Nilai } \\
\text { Sig. }\end{array}$} \\
\hline & & \multicolumn{2}{|c|}{$\begin{array}{c}\text { Salah } \\
\text { melakukan }\end{array}$} & \multicolumn{2}{|c|}{$\begin{array}{c}\text { Benar } \\
\text { Melakukan }\end{array}$} & \multicolumn{2}{|c|}{$\begin{array}{c}\text { Salah } \\
\text { melakukan }\end{array}$} & \multicolumn{2}{|c|}{$\begin{array}{c}\text { Benar } \\
\text { melakukan }\end{array}$} & \\
\hline & & $\mathbf{F}$ & $\%$ & $\mathbf{F}$ & $\%$ & $\mathbf{F}$ & $\%$ & $f$ & $\%$ & \\
\hline 1 & $\begin{array}{l}\text { Tiarap, melindungi kepala dan } \\
\text { berpegangan. }\end{array}$ & 13 & 33.3 & 26 & 66.7 & 5 & 12.8 & 34 & 87.2 & 0.01 \\
\hline 2 & $\begin{array}{l}\text { Berlindung di bawah meja atau } \\
\text { kursi yang kokoh atau } \\
\text { menghadap dinding dalam } \\
\text { sambal berpegangan. }\end{array}$ & 12 & 30.8 & 27 & 69.2 & 7 & 17.9 & 32 & 82.1 & 0.20 \\
\hline 3 & $\begin{array}{l}\text { Jika tidak ada meja atau kursi; } \\
\text { melindungi kepala dan wajah } \\
\text { dengan } \quad \text { lengan sambil }\end{array}$ & 17 & 43.6 & 22 & 56.4 & 8 & 20.5 & 31 & 79.5 & 0.04 \\
\hline
\end{tabular}




\begin{tabular}{|c|c|c|c|c|c|c|c|c|c|c|}
\hline \multirow{3}{*}{ No } & \multirow{3}{*}{$\begin{array}{c}\text { Pernyataan } \\
\text { Tindakan Kesiagaan saat } \\
\text { Bencana }\end{array}$} & \multicolumn{4}{|c|}{ Nilai Pre-test } & \multicolumn{4}{|c|}{ Nilai Post-test } & \multirow{3}{*}{$\begin{array}{l}\text { Nilai } \\
\text { Sig. }\end{array}$} \\
\hline & & \multicolumn{2}{|c|}{$\begin{array}{c}\text { Salah } \\
\text { melakukan }\end{array}$} & \multicolumn{2}{|c|}{$\begin{array}{c}\text { Benar } \\
\text { Melakukan }\end{array}$} & \multicolumn{2}{|c|}{$\begin{array}{c}\text { Salah } \\
\text { melakukan }\end{array}$} & \multicolumn{2}{|c|}{$\begin{array}{c}\text { Benar } \\
\text { melakukan }\end{array}$} & \\
\hline & & $\mathbf{F}$ & $\%$ & $\mathbf{F}$ & $\%$ & $\mathbf{F}$ & $\%$ & f & $\%$ & \\
\hline & $\begin{array}{l}\text { merangkak menuju ke sudut } \\
\text { bangunan. }\end{array}$ & & & & & & & & & \\
\hline 4 & Jangan menggunakan elevator & 31 & 79.5 & 8 & 20.5 & 2 & 5.1 & 37 & 94.9 & 0.00 \\
\hline 5 & $\begin{array}{l}\text { Jauhi kaca, jendela, pintu dan } \\
\text { dinding di luar gedung, dan apa } \\
\text { pun yang bisa jatuh, seperti } \\
\text { lampu dan perabotan. }\end{array}$ & 22 & 56.4 & 17 & 43.6 & 7 & 17.9 & 32 & 82.1 & 0.00 \\
\hline 6 & $\begin{array}{l}\text { Jika Anda berada di tempat } \\
\text { tidur saat gempa, tetaplah di } \\
\text { tempat tidur. Pegang dan } \\
\text { lindungi kepala Anda dengan } \\
\text { bantal; kecuali jika tempa tidur } \\
\text { Anda berada di bawah lampu } \\
\text { berat yang dapat jatuh, } \\
\text { berpindahlah segera ke tempat } \\
\text { aman yang terdekat. }\end{array}$ & 22 & 56.4 & 17 & 43.6 & 0 & 0 & 39 & 100.0 & 0.00 \\
\hline 7 & $\begin{array}{l}\text { Tetap di dalam ruangan sampai } \\
\text { guncangan gempa berhenti. } \\
\text { Jika guncangan berhenti maka } \\
\text { merupakan waktu yang aman } \\
\text { untuk pergi ke luar. Sebagian } \\
\text { besar cedera selama gempa } \\
\text { burusaha keluar dari bangunan. }\end{array}$ & 23 & 59.0 & 16 & 41.0 & 0 & 0 & 39 & 100.0 & 0.00 \\
\hline 8 & $\begin{array}{l}\text { Berhati-hatilah bahwa listrik } \\
\text { dapat saja padam atau sistem } \\
\text { pemadam api atau alarm } \\
\text { kebakaran } \\
\text { menyala. }\end{array}$ & 31 & 79.5 & 8 & 20.5 & 0 & 0 & 39 & 100.0 & 0.00 \\
\hline 9 & $\begin{array}{l}\text { Jika Anda berada di luar } \\
\text { ruangan, tetaplah di tempat. }\end{array}$ & 29 & 74.4 & 10 & 25.6 & 1 & 2.6 & 38 & 97.4 & 0.00 \\
\hline 10 & $\begin{array}{l}\text { Jauhilah bangunan, pohon, } \\
\text { lampu jalan, dan jaringan } \\
\text { kabel. }\end{array}$ & 29 & 74.4 & 10 & 25.6 & 4 & 10.3 & 35 & 89.7 & 0.00 \\
\hline 11 & $\begin{array}{l}\text { Jika Anda berada di dalam } \\
\text { mobil, maka berhentilah segera } \\
\text { dengan aman, arahkan mobil ke } \\
\text { sisi jalan, dan tetaplah berada } \\
\text { di dalam mobil. }\end{array}$ & 29 & 74.4 & 10 & 25.6 & 4 & 10.3 & 35 & 89.7 & 0.00 \\
\hline 12 & $\begin{array}{l}\text { Hindarikan untuk berhenti di } \\
\text { dekat atau di bawah bangunan, } \\
\text { pohon, jalan layang, dan } \\
\text { jaringan kabel. }\end{array}$ & 30 & 76.9 & 9 & 23.1 & 3 & 7.7 & 36 & 92.3 & 0.00 \\
\hline 13 & $\begin{array}{l}\text { Jangan mencoba } \\
\text { mengemudikan kendaraan } \\
\text { melintasi jembatan atau } \\
\text { jembatan yang telah rusak. }\end{array}$ & 29 & 74.4 & 10 & 25.6 & 2 & 5.1 & 37 & 94.9 & 0.00 \\
\hline 14 & $\begin{array}{l}\text { Lanjutkan kembali perjalanan } \\
\text { Anda dengan hati-hati setelah } \\
\text { gempa }\end{array}$ & 27 & 69.2 & 12 & 30.8 & 1 & 2.6 & 38 & 97.4 & 0.00 \\
\hline 15 & $\begin{array}{l}\text { telah berhenti, perhatikan } \\
\text { kerusakan jalan dan jembatan. } \\
\text { Gunakan SMS untuk meminta } \\
\text { pertolongan jika anda } \\
\text { membutuhkannya. }\end{array}$ & 4 & 10.3 & 35 & 89.7 & 0 & 0 & 39 & 100 & 0.04 \\
\hline & RERATA TOTAL & & 59.5 & & 40.5 & & 7.25 & & 92.48 & \\
\hline
\end{tabular}

\begin{tabular}{cccccc}
\hline Paired t-test & & & & Sig. (2-Tailed) & $=0.004$ \\
\hline Hasil & analisa & data tersebut & kesiagaan mahasiswa terhadap bencana \\
menunjukan & bahwa & keterampilan & gempa bumi saat sebelum dilakukan
\end{tabular}


pendekatan drilling adalah dalam kategori rendah (40,5\%). Hasil ini menunjukkan bahwa mahasiswa walaupun terlihat telah memperoleh informasi dari beragam sumber informasi tentang gempa masih belum memiliki keterampilan kesiagaan terhadap gempa yang baik. Ini berarti para mahasiswa masih bukan saja membutuhkan informasi namun lebih dari itu memerlukan suatu program simulasi respons gempa yang nyata dan terarah.

Rendahnya kesiagaan siswa juga terindikasi dalam sebuah penelitian dilakuka terhadap siswa-siswi SMPN 1 Gantowarno Kabupaten Klaten (Ristiyani, 2014) yang mendapati bahwa kesiagaan bencana gempa para siswa didapati rendah $39,53 \%$. Kondisi rendahnya kesigaan ini menjadikan masyarakat rentan terhadap resiko bencana (BNPB, 2017). Kesiapsiagaan menjadi kunci dalam manajemen bencana dengan tujuan utama mengurangi resiko dan jumlah korban jiwa saat bencana terjadi.

Hasil analisa data tersebut menunjukan bahwa tingkat keterampilan kesiagaan mahasiswa tentang kesiagaan bencana gempa saat sesudah dilakukannya promosi dan drilling kesiagaan bencana gempa dalam kategori baik dengan nilai $92,48 \%$. Nilai rerata ini terlihat melonjak dari nilai sebelum promosi dan kegiatan drilling yaitu $40,5 \%$ yang menunjukkan peningkatan perilaku kesiagaan sekitar $50 \%$. Peningkatan kesiagaan dengan pendekatan promosi dan pelatihan juga terbukti efektif dalam penelitian yang dilakukan (Daud R., 2014) yang menunjukkan pelonjakan perilaku kesiagaan 20,2\% dari 76,9\% saat sebelum pelatihan menjadi $97,1 \%$ saat setelah pelatihan.

Peningkatan perilaku kesigaan berarti meningkatkan kapasitas masyarakat dalam merespons bencana gempa dan yang berarti memperkecil resiko bertambahnya korban jiwa saat bencana terjadi. Pelaksanaan pelatihan dan promosi kesiagaan menjadi pendekatan yang esensial dalam mempersiapkan masyarakat yang tangguh bencana (BNPB, 2017)

Hasil analisa data tersebut menunjukan bahwa tingkat kesiagaan bencana mahasiswa saat sebelum dan sesudah dilakukan promosi dan drilling kesiagaan bencana gempa didapati berbeda secara signifikan dengan nilai $p<$ 0,05 . Hal ini menunjukkan bahwa promosi dan drilling kesiagaan bencana gempa mampu meningkatkan tingkat kesiagaan sebanyak 51,98\%. Dapat terlihat bahwa dengan pendekaatan promosi dan drilling kesiagaan bencana gempa yang masih bersifat insidentil dapat memberi pengaruh yang baik terhadapkesigaan individu, maka diharapkan jika promosi dan drilling kesiagaan bencana gempa yang dilakukan secara berkesinambungan akan menumbuhkan ketangguhan bencana gempa dalam masyarakat. Tingginya kemampuan dalam menghadapi gempa merupakan salah satu pendekatan terpenting untuk menurunkan resiko saat bencana terjadi atau yang sering disebut 
disaster risk reduction (DRR) (Onstada PA, 2012).

Pelatihan juga terbukti efektif dalam meninkatkan pengetahuan dan kesiagaan siswa dalam penelitian yang dilakukan (Handy I R Moseya, 2019) yang menunjukkan bahwa terdapat perbedaan kesiagaan dan pengetahuan pada nilai pretest dan posttest dengan nilai total yang signifikansi $\mathrm{p}=0.001$.

Pemberian metode simulasi kesiagaan bencana gempa bumi memberikan pengaruh terhadap anak sekolah dasar di SDN Giwangan Yogyakarta Tahun 2014 antara scbcblum dan sesudah dilakukan simulasi, berdasarkan hasil penelitian yang dilakukan (Indriasari, 2016), menunjukkan dengan nilai yang signifikansi $(\mathrm{P}<0,001)$ sehingga target kecakapan anak-anak untuk bisa menolong diri sendiri tercapai.

Pendekatan metode simulasi juga terbukti dapat memberikan pengaruh dalam meningkatkan kesiagaan siswa SDN Giwangan, Yogyakarta (Indriasari, 2016). Hasil penelitian tersebut melalui pemberian metode simulasi siaga bencana gempa bumi memberikan pengaruh positif terhadap kesiapsiagaan menghadapi bencana gempa bumi pada anak-anak.

\section{KESIMPULAN}

Setelah melewati proses analisa dan interprestasi pada data yang telah dikumpulkan, maka penulis mengambil beberapa kesimpulan yang dapat ditarik dari data tersebut. Adapun kesimpulan dari penelitian ini adalah:

1. Keterampilan kesiagaan mahasiswa terhadap bencana gempa bumi saat sebelum dilakukan pendekatan drilling adalah dalam kategori rendah $(40,5 \%)$.

2. Keterampilan kesiagaan mahasiswa tentang kesiagaan bencana gempa saat sesudah dilakukannya promosi dan drilling kesiagaan bencana gempa dalam kategori baik dengan nilai $92,48 \%$.

3. Tingkat kesiagaan bencana mahasiswa saat scbclum dan sesudah dilakukan promosi dan drilling kesiagaan bencana gempa didapati berbeda secara signifikan dengan nilai $\mathrm{p}<$ 0,05. Hal ini menunjukkan bahwa promosi dan drilling kesiagaan bencana gempa mampu meningkatkan kesiapsiagaan bencana.

\section{SARAN}

Untuk mencapai masyarakat tangguh bencana, perlu langkah-langkah konkrit, sehingga segala program kesiapsiagaan bencana dapat tercapai. Berikut saransaran yang dapat dilakukan agar ketangguhan bencana dapat tercapai.

Bagi Mahasiswa yang sudah paham mengenai kesiapsiagaan menghadapi bencana gempa bumi, berupa pengetahuan dan sikap kesiagaan terhadap risiko bencana gempa bumi, rencana tanggap darurat terhadap bencana, sistem peringatan bencana, dan kemampuan memobilisasi sumber daya dapat menjadi 
agen dalam memberikan pemahaman kepada masyarakat melalui KKN tematik tangguh bencana.

Pemerintah ataupun lembaga swasta perlu mengambil peran aktif dalam melakukan program-program promosi dan simulasi tanggap bencana yang berhubungan. Hal ini bertujuan mempersipakan masyarakat yang tinggal di daerah rawan bencana untuk terus meningkatkan pengetahuannya tentang cara yang tepat dalam menghadapi datangnya bencana khusunya bencana gempa bumi.

\section{UCAPAN TERIMAKASIH}

Penulis ingin mengucapkan terimaksih kepada pihak-pihak yang telah berkontribusi dalam penulisan artikel ini. Terimaksih kepada Bpk. Dr. Samuel Maju Simanjuntak, Bpk Denny Ricky, Ibu Nurhayati Siagiaan, Ibu Morry Peranginangin serta pimpinan Universitas Advent Indonesia yang telah memberikan kontribusi dalam proses pengambilan data. Serta segala masukan yang sifatnya menyempurnakan penulisan ini.

\section{DAFTAR PUSTAKA}

1. Amri, A., (2017). Pendidikan tangguh Bencana. [Online]. Tersedia: http://repositori.kemdikbud.go.id/6107 /1/BukuNotesBencana2017.pdf

2. Badan Meteorologi, Klimatoligi dan Geofisika. (2018, 10 18). Sosialisasi Mitigasi Bencana Gempabumi untuk Kesiapsiagaan di Sampoerna Strategic Square. Retrieved 06 02,
2019, from www.bmkg.go.id: https://www.bmkg.go.id/berita/?p=s osialisasi-mitigasi-bencanagempabumi-untuk-kesiapsiagaan-disampoerna-strategic-square\&lang=ID

3. BNPB. (2017). Buku Pedoman Kesiapsiagaan Bencana: Membangun kesadaran, kewaspadaan dan kesiapsiagaan dalam menghadapai bencana. Jakarta: BNPB.

4. BNPB. (2019). Potensi dan Ancaman Bencana. [Online]. Tersedia: https://www.bnpb.g o.id/home/potensi.html [06 Maret 2019]

5. BNPB. (2018). Panduan Kesiapsiagaan Bencana untuk Keluarga. In B. N. Bencana, Panduan Kesiapsiagaan Bencana untuk Keluarga (p. 8). Jakarta: BNPB.

6. Daud R., S. A. (2014). Penerapan pelatihan siaga bencana dalam meningkatkan pengetahuan, sikap, dan tindakan siswa SMAN 5 di Aceh. Jurnal Ilmu Kebencanaan, 26-34.

7. Handy I R Moseya, C. E. (2019). Kesiapsiagaan Siswa dalam Menghadapi Bencana Gempa Bumi dan Letusan Gunung Berapi Somputan. Jurnal MIPA UNSRAT, 33-35.

8. Indriasari, F. N. (2016). PENGARUH PEMBERIAN METODE SIMULASI SIAGA BENCANA GEMPA BUMI. Jurnal Keperawatan Soedirman, Vol 11, No 3. IIal. 1-7. 
9. Mercalli, (2015). Available [Online]https://www.researchgate.net/ figure/Seismic-intensity-ModifiedMercalli-scale-distribution-of-the2015-Gorkha-Nepal_fig2_308612648

10. Onstada PA, D. S. (2012). The road to recovery from a natural disaster: voices from the. Community Development., 566-580.

11. Ristiyani. (2014, 05 13). KESIAPSIAGAAN SISWA DALAM MENGHADAPI BENCANA. Retrieved $06 \quad 07, \quad 2019, \quad$ from http://eprints.ums.ac.id/30598/: http://eprints.ums.ac.id/30598/1/HA LAMAN AWAL.pdf.
12. Riki, A., (2018). 4 Alasan kenapa Indonesia Sering Terjadi Gempa Bumi. [Online]. Tersedia: https://www.idntimes.com/science/dis covery/aswar-riki/4-alasan-kenapa-diindonesia-sering-terjadi-gempa-bumic1c2/full

13. Statista, (2016). Available at https://www.statista.com/statistics/2 63108/global-death-toll-due-toearthquakes-since-2000/

14. Wawan, A., \& Dewi, 2010, Teori \& Pengukuran Pengetahuan Sikap Dan Prilaku Manusia. Yogyakarta, Nuha medika 